\title{
Strategi Mempertahankan Hubungan Pertemanan Lawan Jenis pada Dewasa Muda
}

\author{
Safira Tiara Dewi ${ }^{1} \mathcal{E}$ Wenty Marina Minza ${ }^{2}$ \\ Fakultas Psikologi Universitas Gadjah Mada
}

\begin{abstract}
Cross-sex friendship is often regarded as a romantic relationship. The lack of social norms that managed these relationships in society makes the individuals dealing with the challenge of maintaining relationships. Young adults become one of the categories that face this challenge because at this time the relationship between men and women is more prominent than the other phases. Based on his romantic intentions, crosssex friendship is divided into four types, strictly platonic, mutual romance, rejects romance, and desires romance. This research was conducted to find out the challenges faced in cross-sex friendship and strategy to maintain the relationship. This research uses qualitative method with phenomenology approach. Methods of data collection used in this study are semi-structured interviews and observation. The study's informants consisted of four people or two pairs of young adults who are in cross-sex friendship. Research shows that individual differences in seeing the friendship of the opposite sex cause different challenges and strategies to maintain cross-sex friendships.
\end{abstract}

Keywords : cross-sex friendship, maintenance behavior strategy, challenges

Abstrak. Hubungan pertemanan lawan jenis sering kali dianggap sebagai hubungan romantis. Kurangnya norma sosial yang mengatur hubungan ini di masyarakat menjadikan individu yang menjalaninya menghadapi tantangan untuk mempertahankan hubungannya. Dewasa muda menjadi salah satu kategori yang menghadapi tantangan ini karena pada masa ini hubungan antara laki-laki dan perempuan lebih menonjol dibandingkan dengan fase lainnya. Berdasarkan intensi romantisnya, pertemanan lawan jenis terbagi ke dalam empat jenis, yaitu platonik, kesamaan perasaan romantis, menolak hubungan romantis dan menginginkan hubungan romantis. Penelitian ini dilakukan untuk mengetahui tantangan yang dihadapi dalam pertemanan lawan jenis dan strategi mempertahankan hubungan yang dilakukan. Penelitian ini menggunakan metode kualitatif dengan pendekatan fenomenologi. Metode pengambilan data menggunakan wawancara semi-terstruktur dan observasi. Informan penelitian ini terdiri dari dua pasang dewasa muda yang menjalani pertemanan lawan jenis. Penelitian menunjukkan bahwa perbedaan individu dalam melihat hubungan pertemanan lawan jenisnya menimbulkan perbedaan dalam tantangan yang dihadapi dan strategi yang dilakukan untuk mempertahankan hubungannya.

Kata kunci : pertemanan lawan jenis, strategi mempertahankan hubungan, tantangan

Manusia merupakan makhluk sosial yang

${ }^{1}$ Korespondensi mengenai isi artikel ini dapat dilakukan melalui safira.tiara.d@mail.ugm.ac.id

2 Atau melalui wminza@ugm.ac.id membutuhkan orang lain untuk bertahan hidup. Manusia melakukan interaksi sosial untuk memenuhi kebutuhannya. Salah satu kebutuhan yang dapat terpenuhi dengan interaksi adalah kebutuhan untuk 
berafiliasi. Kebutuhan berafiliasi merupakan kebutuhan untuk mendapatkan kehadiran orang lain dalam kehidupan seseorang. Interaksi sosial yang berkelanjutan akan menghasilkan hubungan interpersonal. Salah satu hubungan interpersonal yang terbentuk adalah pertemanan. Pertemanan merupakan hubungan dua individu yang menghabiskan banyak waktu bersama, berinteraksi dalam segala kondisi dan saling memberikan dukungan emosi (Baron \& Branscombe, 2012). Berdasarkan perbedaan kualitasnya, pertemanan dapat dikategorikan menjadi tiga yaitu teman, teman dekat, dan sahabat. Penggunaan istilah 'teman' dalam lingkungan sosial di Indonesia memiliki perbedaan dengan istilah 'friend' di Australia (Robinson, 2016). Penelitian yang dilakukan oleh peneliti Australia di Minangkabau menyatakan bahwa teman dalam konteks Indonesia mengandung arti luas, mengacu pada sekelompok orang yang memiliki relasi rendah. Peneliti tersebut mengamati dalam ruang kelas yang berisikan 60 siswa dimana seluruh siswa dalam kelas dianggap sebagai 'teman' bagi satu sama lainnya, sedangkan di Australia merupakan hal yang wajar ketika 'teman' adalah individu yang berada dalam kelompok kecil di ruang kelas. Teman dalam hal ini berada pada level dasar dalam hubungan pertemanan antar individu, yang memiliki potensi untuk dikembangkan seiring dengan interaksi yang berkelanjutan. Teman dapat dikategorikan sebagai individu yang kita kenal atau acquaintance (Kaplan, 1999). Hubungan ini memiliki ekslusifitas yang rendah dibandingkan dengan hubungan yang lainnya. Individu hanya mengenal individu lain tanpa saling memiliki informasi yang mendalam terhadap satu sama lain.
Individu yang memiliki teman dekat atau close friend memberikan perasaan kasih sayang terhadap satu sama lain (Miller, 2015). Mereka yang berada dalam hubungan ini memiliki kepercayaan dan menghormati satu sama lain, serta menghargai loyalitas. Individu dalam hubungan ini akan merasa bebas atau leluasa untuk menjadi diri sendiri. Teman dekat memiliki tingkat keintiman yang sedang dibandingkan dengan sahabat yang memiliki tingkat keintiman yang lebih tinggi.

Persahabatan atau best friend merupakan hubungan interpersonal antara dua individu yang produktif dan positif (DeVito, 1995). Hubungan yang terjalin dalam persahabatan harus saling membangun kearah yang positif. Persahabatan adalah hubungan suka rela yang memiliki keintiman, saling menolong, dan kedua individu saling menginginkan kehadiran sahabat dalam hidupnya (Fehr, dalam Miller, 2015). Sahabat merupakan salah satu sumber kebahagiaan bagi individu, karena keintiman yang terbentuk dapat melebihi jenis hubungan interpersonal yang lainnya. Dalam penelitian yang dilakukan sebelumnya di Minangkabau, sahabat dapat berarti 'teman akrab' atau 'teman curhat' (Robinson, 2016). Teman akrab merupakan istilah yang sering dipakai oleh laki-laki untuk mengatakan bahwa individu yang ditunjuk adalah sahabatnya, sedangkan perempuan lebih sering menggunakan istilah 'teman curhat' untuk sahabatnya. Teman curhat berarti teman yang dapat mendengarkan isi hati kita (curhat $=$ mencurahkan isi hati). Perempuan menggunakan istilah ini karena persahabatan antar perempuan lebih didominasi dengan pembicaraan mengenai perasaan. Karakteristik pada persahabatan adalah memberikan dorongan kepada individu lain untuk 
meningkatkan potensi yang ada dalam diri individu tersebut (DeVito, 1995). Individu dalam persahabatan tidak boleh melakukan hal yang dapat menghancurkan diri sendiri atau sahabatnya. Kepercayaan menjadi unsur yang penting dalam persahabatan. Kepercayaan memakan waktu yang lama untuk terbentuk, namun kepercayaan dapat membuat individu menjadi lebih tenang dan nyaman dalam menjalani persahabatannya (Miller, 2015). Individu yang tidak memiliki kepercayaan dalam hubungan persahabatan yang dijalaninya akan menjadi waspada dan berhati-hati dalam bertindak. Sahabat memberikan dukungan saat menghadapi situasi yang sulit. Dukungan yang diberikan dapat berupa materi, dukungan emosional atau dukungan sosial.

Berdasarkan jenisnya, pertemanan terbagi menjadi dua, yaitu pertemanan sesama jenis dan pertemanan lawan jenis. Perempuan memiliki lebih banyak teman dekat, keterbukaan dan saling mendukung satu sama lain dibandingkan dengan pertemanan antar laki-laki (Dow \& Wood, dalam Santrock, 2011). Keterbukaan yang ada dalam pertemanan perempuan melibatkan aktifitas mendengarkan satu sama lain dan bersimpati. Pertemanan pada laki-laki lebih banyak melibatkan aktifitas atau melakukan kegiatan bersama seperti olahraga, bermain game, dan aktifitas di luar ruangan (Santrock, 2011). Pertemanan laki-laki tidak terlalu terlibat dalam pembicaraan mengenai perasaan dan simpati. Selain pertemanan sesama jenis, terdapat pertemanan lawan jenis. Pertemanan lawan jenis adalah hubungan non-romantis yang dijalani oleh individuindividu yang berlawanan jenis (Monsour, 2002). Hubungan ini berkembang sepanjang rentang hidup manusia. Pada masa anak-anak, pertemanan lawan jenis sudah mulai terbentuk. Salah satu bentuk pertemanan yang terlihat adalah ketika masing-masing individu yang terlibat saling memberikan perlindungan dari kekerasan yang dilakukan teman sebayanya di sekolah (Monsour, 2002). Bentuk perlindungan yang diberikan seperti misalnya menyuruh temannya berhenti mengejek sahabatnya. Beranjak dari masa anak-anak, pertemanan berlanjut pada masa remaja. Pada masa ini remaja sudah memiliki pemaknaan yang lebih matang mengenai pertemanan. Karakteristik pertemanan pada masa remaja adalah adanya tingkatan keintiman yang lebih tinggi dibandingkan dengan tahapan sebelumnya (Rubin, dalam Monsour, 2000). Masa remaja yang ditandai dengan adanya pubertas membuat dinamika pertemanan pada masa ini menjadi menarik, namun pada kenyataannya pubertas yang dialami setiap remaja laki-laki dan perempuan berbeda. Pubertas pada masa ini memengaruhi cara pandang remaja terhadap dirinya dan orang lain, khususnya terhadap lawan jenis. Pertemanan terlihat lebih menonjol pada dewasa muda. Berdasarkan teori psikososial Erikson, dewasa muda usia 1930 tahun mulai memasuki konflik intimacy vs isolation. Dewasa muda memiliki kemampuan untuk meleburkan identitasnya dengan orang lain tanpa ketakuan untuk kehilangan identitasnya (intimacy). Dewasa awal yang berhasil menemukan makna keintiman sesungguhnya akan berbagi kepercayaan yang sama dengan orang lain. Hubungan interpersonal yang dijalani dewasa muda dibutuhkan pengorbanan, kompromi, dan komitmen dalam hubungan dua individu yang setara (Feist \& Fiest, 2009). Di masa ini, dewasa muda dianggap telah menemukan jati dirinya, sehingga hubungan interpersonal yang dijalani lebih dewasa. Bentuk pertemanan lawan 
jenis lebih berpotensi terbentuk pada dewasa muda, karena pada masa ini sanksi sosial cenderung melemah (Baumgarte, 2002).

Kedua individu yang menjalin hubungan tersebut secara tidak langsung akan mendapatkan keuntungan. Berdasarkan penelitian yang sudah dilakukan sebelumnya, laki-laki merasakan kepuasan yang lebih besar dalam menjalin hubungan pertemanan dengan perempuan. Laki-laki yang mengalami stres cenderung akan mencari teman perempuannya untuk mendapatkan dukungan emosional (Baumgarte, 2002). Dukungan emosional lebih sering didapatkan dari teman perempuan dibandingkan dengan teman laki-laki, sehingga hubungan ini memberikan keuntungan bagi kaum laki-laki. Tidak hanya laki-laki, perempuan pun merasakan keuntungan dari menjalin hubungan ini. Perempuan akan mendapatkan pendapat atau saran berdasarkan perspektif lawan jenis. Memiliki sahabat lawan jenis akan meningkatkan pemahaman dan penerimaan antar gender, menurunkan sexism dan sexual harassment, serta memperkaya diri karena memiliki seorang teman yang berbeda dari diri sendiri (Kaplan \& Keys, Monsour, Werking, dalam Baumgarte, 2002).

Pertemanan lawan jenis masih dilihat sebagai hubungan yang tidak lazim di masyarakat. Norma sosial yang dipegang masyarakat masih terbatas dalam mengatur bagaimana individu dalam pertemanan lawan jenis di masyarakat. Norma sosial merupakan pedoman yang mengatur tentang bagaimana seseorang berperilaku di masyarakat. Keterbatasan tersebut memunculkan steriotip-steriotip mengenai pertemanan lawan jenis. Masyarakat memiliki steriotip bahwa hubungan antara laki-laki dan perempuan adalah hubungan yang romantis, bahkan ada kalangan yang menganggap bahwa hubungan pertemanan antara laki-laki dan perempuan adalah hubungan yang tidak mungkin terjadi. Adanya ambiguitas batas antara pertemanan lawan jenis dan hubungan romantis memperkuat anggapan tersebut. Individu-individu yang menjalani pertemanan lawan jenis harus berhati-hati dalam bertingkah laku di lingkungannya, agar tidak dianggap sebagai pasangan romantis atau pasangan yang berpotensi untuk melanjutkan hubungan menjadi hubungan yang romantis (Monsour, 2002). Pandangan orang lain mengenai hubungan pertemanan lawan jenis yang sering disalah artikan sebagai hubungan romantis dikategorikan sebagai audience challenge atau tantangan pihak eksternal, salah satu tantangan yang dialami oleh individu yang menjalani pertemanan lawan jenis (Helgeson, 2012). O'Meara (1989) menyatakan bahwa ada empat tantangan yang dihadapi oleh individu yang menjalani pertemanan lawan jenis, yaitu tantangan ikatan emosional, tantangan pihak eksternal, tantangan kesetaraan dan tantangan ketertarikan seksual. Tantangan pihak eksternal merupakan salah satu tantangan yang berhubungan dengan pihak ketiga atau individu yang berada di luar hubungan tersebut. Pihak ketiga dapat berasumsi bahwa hubungan tersebut adalah hubungan romantis, karena hubungan ini tidak memiliki cultural script di masyarakat (Baumgarte, 2002) yang berarti suatu konteks untuk bertindak atau melakukan sesuatu yang mencerminkan peran yang pantas sehingga tindakan individu-individu yang terlibat di dalam situasi tersebut memiliki makna (O'Meara, 1989). Perkembangan di dalam suatu hubungan dipengaruhi oleh pedoman 
atau script yang terbentuk dari definisi situasi, identitas dari individu yang terlibat, dan rentang serta urutan perilaku yang dapat diterima (Michener \& John D, 1999). Individu yang menjalani pertemanan lawan jenis menemukan kesulitan karena tidak adanya pedoman yang jelas tentang bagaimana laki-laki dan perempuan berteman di masyarakat.. Salah satu sumber yang memengaruhi pembentukkan pedoman ini adalah media massa. Laki-laki dan perempuan mempelajari suatu hubungan dari majalah, film, novel, dan media massa lainnya. Tantangan selanjutnya adalah tantangan ikatan emosional, tantangan ini merupakan tantangan bagi individu untuk memahami makna emosi yang mereka rasakan dan berikan. Tantangan ini merupakan salah satu tantangan tersulit berdasarkan hasil survey yang dilakukan Monsour kepada mahasiswa yang menjalin hubungan pertemanan lawan jenis (Monsour, dalam Helgeson, 2012). Mereka yang menjalani hubungan ini akan menghadapi tantangan untuk membentuk 'mutual nonromantic emotional bond', yaitu hubungan emosi non-romantis yang dimiliki setiap individu yang terlibat di dalamnya. . Ketertarikan seksual sering disebut sebagai salah satu tantangan terberat bagi individu yang tidak memiliki pasangan romantis. Kedekatan yang terjadi di antara kedua individu dapat mengarahkan hubungan tersebut ke dalam ketertarikan seksual. Ketertarikan seksual dapat menjadi dasar hubungan pertemanan lawan jenis, namun tujuan dari hubungan pertemanan tersebut berubah menjadi hubungan untuk mendapatkan kepuasan seksual. Hubungan seperti ini lebih umum ditemukan di Barat dan dikenal dengan istilah friends with benefits, gabungan dari hubungan pertemanan dan keintiman seksual yang tidak memiliki komitmen seperti pasangan romantis (Afifi \& Faulkner, 2000). Walaupun hubungan pertemanan lawan jenis berarti tidak ada. Kesetaraan merupakan tantangan mengenai kesetaraan antar individu dalam pertemanan lawan jenis. Pertemanan lawan jenis seharusnya bukan menjadi hubungan yang timbal-balik, tetapi menjadi hubungan yang komunal (O'Meara, 1989). Dalam hubungan yang timbal-balik, status laki-laki dan perempuan dalam hubungan ini menjadi penting karena individu yang memiliki power yang lebih tinggi akan mendominasi hubungan tersebut.

Terdapat empat cara untuk melihat pertemanan lawan jenis berdasarkan intensi romantis yang dikemukakan oleh Guerrero dan Chavez (2005), yaitu strictly platonic, mutual romance, desires romance dan rejects romance. Strictly platonic atau platonik yang kuat merupakan jenis hubungan dimana salah satu individu yang terlibat tidak ingin mengubah hubungan pertemanan menjadi hubungan romantis dan percaya bahwa individu yang lainnya juga tidak menginginkan hubungan romantis. Mutual romance atau adanya kesamaan perasaan romantis, jenis hubungan ini individu menghendaki perubahan hubungan pertemanan menjadi hubungan romantis dan meyakini bahwa individu yang lainnya juga menginginkan hal yang sama. Desires romance atau adanya keinginan menjalin hubungan romantis, salah satu individu menginginkan hubungan berlanjut ke hubungan romantis dan percaya bahwa individu lainnya tidak menginginkannya, Rejects romance atau penolakan hubungan romantis, merupakan hubungan dimana individu tidak menginginkan adanya hubungan romantis namun individu lainnya menginginkan hubungan romantis. 
Pandangan yang salah terhadap hubungan ini dapat berdampak pada individu yang menjalaninya. Jika pihak eksternal melihat hubungan ini sebagai hubungan romantis, maka individu yang terlibat di dalamnya harus mengatur pandangan pihak eksternal agar kemurnian pertemanan yang dijalaninya tersampaikan (O'Meara, 1989). Proses adaptasi kedua individu tersebut terhadap lingkungan seperti itu akan menimbulkan tekanan tersendiri bagi yang menjalaninya. Apabila pihak eksternal tetap mengasumsikan bahwa hubungan tersebut adalah hubungan romantis dan memberikan tekanan agar kedua individu tersebut menjadi pasangan romantis, maka pertemanan yang dijalani oleh keduanya akan menjadi renggang (Rawlins, dalam Schoonover \& McEwan, 2014). Untuk menghindari kesalahpahaman, individu harus menyeimbangkan antara apa yang dirasakan orang lain dan apa yang sesungguhnya terjadi di dalam hubungan tersebut, sehingga kedua individu dapat mempertahankan hubungannya.

Menyadari adanya tantangan yang harus dihadapi oleh pasangan pertemanan lawan jenis, individu berusaha untuk mempertahankan hubungannya. Bentuk tindakan yang dilakukan masing-masing individu untuk mempertahankan hubungannya tercermin dalam maintenance behavior atau strategi mempertahankan hubungan. Perilaku mempertahankan hubungan tersebut dilakukan untuk menjaga hubungan agar tetap sesuai dengan yang diinginkan.

Penelitian ini dilakukan untuk mengetahui tantangan yang dihadapi oleh dewasa muda yang menjalani pertemanan lawan jenis dan bagaimana individu di dalamnya mempertahankan hubungan tersebut. Penelitian ini dapat mengembangkan ilmu yang telah ada, khususnya dalam hubungan interpersonal yang mengkaji pertemanan. Hasil dari penelitian ini dapat membuka wawasan masyarakat terhadap hubungan pertemanan lawan jenis dan membantu individu untuk mempertahankan hubungannya.

\section{Metode}

Penelitian ini menggunakan metode penelitian kualitatif dengan pendekatan fenomenologi. Pengambilan data menggunakan in-depth interview dan menggunakan pedoman wawancara semiterstruktur. Subjek penelitian dipilih melalui purposeful sampling. Subjek penelitian ini adalah dua pasang individu pertemanan lawan jenis, laki-laki dan perempuan berusia 20-25 tahun, memiliki hubungan pertemanan yang dekat, dan berdomisili di Yogyakarta. Observasi partisipatif dan wawancara significant other juga dilakukan sebagai data pendukung. Analisis data menggunakan Interpretative Phenomenological Analysis atau IPA. IPA merupakan teknik yang melakukan pemeriksaan (examination) pada individu mengenai bagaimana individu tersebut memaknai peristiwa dalam hidupnya. Pengujian keabsahan data menggunakan triangulasi data dengan mengkolaborasikan hasil wawancara dan observasi.

\section{Hasil}

Berdasarkan hasil dari pengambilan data, ditemukan bahwa kedua pasang informan EM, AR dan VN, AL mengatakan bahwa terdapat perbedaan dalam mendefinisikan teman dan sahabat. Hubungan yang dijalin dengan sahabat dapat dikatakan lebih erat dan lebih intim. Pembicaraan yang dilakukan dengan teman hanya sekedar percakapan biasa, sedangkan dengan sahabat percakapan yang terjalin 
dapat meliputi permasalahan pribadi. Teman adalah seseorang yang dikenal namun tidak membicarakan hal pribadi, sedangkan sahabat adalah seseorang yang dapat dipercaya untuk membicarakan hal pribadi. Keempat informan juga mengungkapkan perbedaan antara pertemanan lawan jenis dan pasangan romantis. Perbedaan diantara keduanya terletak pada kontak fisik yang terjadi. Kontak fisik lebih sering terjadi pada pasangan romantis dibandingkan dengan pasangan pertemanan lawan jenis. Kedua pasangan menunjukkan karakteristik yang sama dalam menjalin pertemanan lawan jenis yaitu menghabiskan waktu bersama, memiliki kesamaan, menjalin hubungan yang timbal-balik, dan saling menceritakan permasalahan pribadi. Pertemanan lawan jenis juga memberikan manfaat bagi individu yang menjalaninya. Manfaat yang dirasakan diantaranya adalah mengetahui perspektif lawan jenis dalam menghadapi permasalahan, dapat memenuhi kebutuhan emosi terutama pada laki-laki, membantu diri untuk menjadi lebih terbuka kepada orang lain, dan terhindar dari rasa kesepian.

Pasangan EM dan AR mengalami tantangan yang berbeda. AR menghadapi tantangan pihak eksternal yang menganggap bahwa hubungannya dengan EM adalah hubungan yang romantis. AR mengatakan bahwa dirinya sering diejek oleh teman-teman laki-lakinya karena sering menghabiskan waktu bersama EM. AR menarik diri dari kelompok teman laki-lakinya setelah dirinya diejek.

“...mereka jadi ngomong gitu di otak aku "iii..udah deket nih sama mereka sekarang" kaya gitu kan. Terus aku agak nahan diri, jadi aku abis dibilang kaya gitu aku langsung kaya agak ngejauh dari EM ini, bukan EM-nya sih, tapi sama kumpulan temen EM..."

(W1.AR.117-120)

AR memiliki strategi untuk menghadapi tantangan tersebut. Ia mengatakan bahwa dirinya akan berusaha untuk menjelaskan kepada teman lakilakinya bahwa hubungannya dengan EM adalah hubungan pertemanan biasa. Selanjutnya ia akan mengalihkan arah pembicaraan agar teman laki-lakinya tidak membahas hal tersebut.

"Ya kalo aku sih aku jelasin aja kalo cuma temenan, nanti aku bakal becanda nanti aku alihin obrolannya hahaha" (W2.AR.83-84)

Penelitian ini juga menemukan tantangan baru yang tidak disebutkan dalam empat tantangan yang dikemukakan oleh O'Meara (1989). Tantangan tersebut adalah tantangan dalam menghadapi situasi romantis. Peneliti menemukan bahwa informan EM menghadapi tantangan dalam menghadapi situasi romantis yang ia rasakan ketika bersama AR. Informan EM menyebutnya dengan click moment yang merupakan situasi saat EM merasa bahwa sebenarnya AR memiliki potensi untuk menjadi kekasihnya, namun karena alasan tetap ingin menjadi sahabat ia tidak mengembangkan perasaannya atas situasi tersebut.

"Click moment itu saat dimana aku ngerasa AR itu adalah orang yang bisa ngertiin aku, kalo aku lagi butuh saran dalam pertimbangan dia ngebilangin aku. Jadi kalo aku bisa bilang click moment itu adalah sesuatu yang kalo aku kembangin itu bakal bikin aku suka sama dia, if only itu bukan AR ya aku bakal suka sama dia" (W2.EM.293-296)

Biasanya situasi yang EM sebut sebagai click moment adalah ketika AR mendengarkan keluhannya di saat EM membutuhkannya. AR juga memberikan 
nasihat kepada EM yang membuat EM merasa bahwa ia dan AR memiliki kecocokan. Tidak hanya mendengarkan keluh kesah EM, AR juga mencoba menghibur EM dengan cara mengajaknya melakukan hal yang menyenangkan.

“..ada beberapa click moment kaya yang misal aku ngobrol waktu itu lebaran adekku tadinya mau balik tapi disuruh nemenin aku yang lagi skripsi, terus aku pengen cerita dan aku telpon si DA yang kebetulan ga diangkat, terus aku nelpon AR. Dia ga ada ngasih saran atau apa dia cuma denger dan dia bilang 'sorry ya gua denger cerita lu yang ini' terus aku bilang aja ga apa-apa dan aku memang pengen cerita ke dia. Terus dia bilang 'yaudah nanti kita karaokean aja' di saat yang aku butuh orang untung dengerin aku bersyukur aja ada dia yang mau dengerin." (W2.EM.45-53)

EM mengatakan bahwa terdapat beberapa cara yang ia lakukan jika situasi yang terjadi diantara EM dan AR menjadi romantis.

"Pokoknya kalo udah care-nya kelewatan ke aku, batasinnya dengan becandaan. Supaya ga terlalu terbawa perasaan. Misalnya kalo dia nganterin aku pulang kos, terus nungguin aku buka gerbang sampe aku masuk kos biasanya aku langsung becandain biar suasananya tuh cair dan aku ga baper. Dulu tuh awal-awal aku kenal dia, dia ga kaya gini, tapi karena udah kenal deket aja aku jadinya tau, kalo engga ya aku bisa aja baper." (W2.EM.298302)

EM akan mengeluarkan candaan ketika situasi berubah menjadi romantis bagi dirinya. Hal ini dirasakan EM ketika hubungannya dengan AR sudah terjalin cukup lama. EM mengetahui bahwa AR adalah orang yang memberikan perhatian kepada teman dekatnya setelah berteman cukup lama dengannya.

Pasangan VN dan AL menghadapi tantangan ikatan emosional. Tantangan ini mengharuskan pasangan untuk membentuk emosi non-romantis dalam hubungannya, namun $\mathrm{VN}$ dan AL tidak berhasil dan mencoba untuk menjalin hubungan romantis. Setelah menjalani hubungan romantis keduanya mengalami konflik dan tidak dapat mempertahankan hubungan romantis tersebut. AL dan VN kemudian mencoba untuk mempertahankan hubungan pertemanan lawan jenis mereka dengan cara tidak menghubungi satu sama lain terlebih dahulu.

“Ee sebenernya kalo gua bilang ya kaya setelah emang agak ngambil space, yang pertama gua waktu itu juga posisinya lagi di Jakarta lagi magang beberapa bulan gitu, terus waktu di Jakarta itu juga gua eeee agak banyak komunikasi sama mantan gua, terus kaya setelah gua balik kesini gua nyelesain skripsi, gua lulus itu gua ngerasa gua kaya kehilangan sebuah persahabatan yang menurut gua sangat berharga, gua baru mulai kontak lagi $\mathrm{VN}$ ya pertama ketemu ya masih awkward gitu." (W1.AL.231-236)

Mereka berdua juga menghindari topik pembicaraan mengenai kegagalan hubungan romantis mereka, namun VN memiliki inisiatif untuk membicarakan hal tersebut sebagai salah satu cara untuk mengembalikkan hubungan mereka seperti dulu.

Iya, aku sih yang nanya-nanya dulu. Pertamanya sih gimana ya, oh aku sempet nanya dia sama cewe yang itu, akhirnya kenapa putus dan segala macem terus eee aku cuma yang ngobrol ngobrol aja ngomongin tentang itu. Ya udahlah kita ga 
usah.. apa yah kita kalo ngomong masih hati-hati gitu kaya takut salah gitu. Yah ya udah lah it happened." (W2.VN.11-14)

AL menunjukkan tantangan baru yang sebelumnya tidak ada, yaitu tantangan self-image atau citra diri. AL merasakan bahwa ia merasa takut jika orang lain menilai dirinya adalah laki-laki yang tidak baik. Hal tersebut disebabkan karena ia memiliki kedekatan dengan beberapa teman perempuannya.

"Ada sih, yang pertama sih karena emang image kalo emang tadi batasan jaraknya udah kaya kelewatan gitu ngelewatin bates, bisa aja diliatin orang ini aneh orang berdua kayanya ini ga cuma temenan gitu misalkan. Misal gua punya sahabat cewe lebih dari dua, dan gua sama semua orang itu ga bisa jaga batasan gua gitu kan ga enak. Gua orangnya ini sih takutan banget" (W1.AL.345-349)

AL mengatakan bahwa dirinya memilih untuk menjaga batasan terhadap $\mathrm{VN}$, karena ia tidak ingin citra dirinya berubah menjadi negatif.

\section{Diskusi}

Berdasarkan intensi romantisnya, pertemanan lawan jenis terbagi menjadi empat (Canary \& Stafford, 1992). Pertemanan yang dijalani oleh EM dan AR adalah hubungan yang platonic atau tidak memiliki perasaan romantis dalam hubungannya. Hubungan VN dan AL pada mulanya adalah hubungan pertemanan yang platonik, namun situasi berubah ketika AL sudah tidak lagi memiliki kekasih. Keduanya memiliki perasaan romantis satu sama lain atau mutual romance, yaitu individu menginginkan hubungan romantis dan meyakini bahwa individu lainnya juga menginginkannya (O'Meara, 1989). Adanya perasaan romantis dalam diri keduanya menjadi dasar hubungan romantis terjalin. Setelah keduanya mengakhiri hubungan mereka, pertemanan yang pada mulanya ada kesamaan romantis berubah menjadi desires romance dan rejects romance.

Pasangan platonik EM dan AR menghadapi tantangan pihak eksternal dan tantangan situasi romantis. Situasi yang tercipta ketika ia bersama $A R$ terkadang menimbulkan perasaan romantis dan ketertarikan. Perilaku yang ditunjukkan AR kepada EM dapat dikatakan sesuai dengan kriteria kekasih yang diinginkan oleh EM. AR terkadang menunjukkan kebaikan dan kepeduliannya terhadap EM. Hal tersebut merupakan contoh atribut yang paling diinginkan seseorang sebagai pasangan romantisnya (Sprecher \& Regan, 2002), namun dalam jurnal tersebut tidak dijelaskan mengenai situasi romantis yang dihadapi individu dalam pertemanan lawan jenis. Hal ini menjadi suatu tantangan karena pada saat yang sama EM tidak menginginkan AR menjadi pasangan romantisnya. Oleh karena itu, EM lebih memilih untuk menghadapi situasi tersebut dengan cara mengalihkan pembicaraan atau bercanda dengan AR agar situasi romantis dapat terhindarkan. AR menghadapi tantangan pihak eksternal dari teman-temannya yang meledek dan menyindir AR ketika dirinya menjalin pertemanan dengan EM. Meskipun AR menerima sindiran dan ejekan tersebut, AR merasakan bahwa tantangan tersebut tidak terlalu berpengaruh terhadap hubungannya dengan EM. Hal ini sesuai dengan penelitian yang pernah dilakukan sebelumnya bahwa pasangan platonik lebih sedikit merasakan tantangan pihak eksternal dibandingkan dengan jenis pasangan yang lainnya (Schoonover \& 
McEwan, 2014). Hal tersebut terjadi karena perilaku yang ditujukan kepada satu sama lain tidak seperti yang dilakukan dalam hubungan romantis. Pihak eksternal cenderung mengira pasangan sahabat lawan jenis sebagai pasangan romantis apabila keduanya memperlakukan satu sama lain seperti pasangan romantis. EM dan AR memperlakukan satu sama lain seperti sahabat pada umumnya, hal ini didukung dengan hasil observasi yang dilakukan peneliti kepada EM dan AR (O1,AR,EM).

Faktor lain yang menyebabkan pasangan platonik lebih jarang menghadapi tantangan pihak eksternal adalah jumlah teman lawan jenis yang dimiliki (Schoonover \& McEwan, 2014). Jika individu sering menghabiskan waktu dengan teman lawan jenis lainnya, maka pihak eksternal akan melihat bahwa hal tersebut menjadi wajar sehingga tidak terbentuk asumsi bahwa hubungan tersebut adalah hubungan romantis. Lingkungan sosial menjadi salah satu faktor pendukung munculnya tantangan ini. Lingkungan sosial yang menerima hubungan antara laki-laki dan perempuan sebagai hubungan pertemanan akan mengurangi kekhawatiran individu atas persepsi orang lain terhadap hubungan yang ia jalani.

Pasangan EM dan AL menghadapi tantangan ikatan emosional. Tantangan ini merupakan tantangan individu dalam pertemanan lawan jenis untuk mendefinisikan tipe cinta yang mereka rasakan (O'Meara, 1989). Setelah menjalin persahabatan dalam kurun waktu yang cukup lama, VN dan AL mengubah cara pandang mereka terhadap hubungan yang mereka jalani menjadi hubungan yang romantis. Berdasarkan jenis ikatan emosional yang dikemukakan oleh Rawlins (1982), VN dan AL memilih untuk menjalin hubungan romantis karena mendefinisikan cinta di antara keduanya sebagai romantic love, yaitu ikatan emosional yang memiliki ekslusifitas. VN dan AL pada akhirnya mengalami kegagalan dalam mendefinisikan perasaan cinta dalam hubungan mereka. Ketidakstabilan emosi dalam mengungkapkan kasih sayang (W1.AL.292-394) merupakan ciri dari friendship love (Rawlins, 1982). VN dan AL pada kondisi ini lebih sesuai menjadi sahabat untuk satu sama lain dibandingkan dengan pasangan romantis, karena ketidakstabilan emosi VN dalam menyampaikan perhatiaanya tidak dapat diterima oleh AL.

Berdasarkan penelitian yang dilakukan di Taiwan mengenai pasangan sahabat lawan jenis, terdapat beberapa cara yang dapat dilakukan untuk mempertahankan hubungan persahabatan setelah hubungan romantis berakhir (Lee, 2010). Lee (2010) menemukan 8 cara untuk pasangan kembali menjalin hubungan persahabatan, yaitu direct strategy, indirect strategy, melalui pihak ketiga, secara kebetulan, saling mendukung, menghindari topik pembicaraan tertentu, berkomunikasi dengan pihak ketiga, dan menjaga jarak. Berdasarkan data yang dikumpulkan, VN melakukan direct $\mathcal{E}$ indirect strategy atau cara langsung dan tidak langsung. Indirect strategy atau strategi tidak langsung adalah cara yang dilakukan individu yang memulai menghubungi sahabatnya untuk menunjukkan bahwa dirinya masih peduli dan ingin memperbaiki hubungan. VN adalah orang pertama yang menghubungi AL terlebih dahulu melalui pesan teks. VN menanyakan kabar dan kehidupan AL setelah beberapa bukan tidak bertukar kabar. VN merasa yakin bahwa dirinya tidak ingin kehilangan sahabat seperti AL. Setelah cukup lama berkomunikasi seperti biasa, VN mulai melakukan strategi secara 
langsung (direct strategy) dengan cara mengutarakan langsung keinginannya untuk menjalin persahabatan kembali dengan AL. VN membicarakan mengenai komunikasi diantara mereka yang menjadi canggung dan terkesan hati-hati setelah mereka mengakhiri hubungan romantisnya. Kemudian keduanya sepakat untuk mencoba bersikap seperti biasa lagi dan menerima bahwa hubungan mereka yang lalu tidak berhasil serta bersamasama mencoba untuk memperbaiki hubungan mereka.

Individu yang sebelumnya pernah memiliki pertemanan yang baik memiliki potensi untuk menjalin hubungan pertemanan kembali setelah hubungan romantis berakhir (Sheehan \& Dillman, dalam Schneider \& Kenny, 2000). VN dan AL memiliki pondasi yang kuat untuk menjalin persahabatan karena keduanya telah bersahabat cukup lama dan sudah mengenal satu sama lain dengan baik. Hubungan pertemanan memiliki potensi untuk terbentuk ketika laki-laki yang memiliki keinginan untuk mengakhiri hubungan romantis tersebut (Schneider \& Kenny, 2000). AL memiliki keinginan untuk mengakhiri hubungan romantisnya dengan VN karena adanya ketidakcocokan, namun bukan berarti AL juga mengakhiri persahabatannya dengan VN.

Pada saat ini, hubungan mereka yang sebelumnya mutual romance atau kesamaan perasaan romantis telah berubah menjadi desires romance dan rejects romance. $\mathrm{VN}$ adalah pihak yang menginginkan hubungan romantis tetap berlangsung (desires romance), namun ia meyakini bahwa AL tidak menginginkannya. Kondisi tersebut dibuktikan dengan tindakan VN untuk terus berkomunikasi dengan AL. Penelitian sebelumnnya menemukan bahwa individu yang berada pada kondisi desires romance akan berusaha untuk komunikasi tetap berlangsung (Schneider \& Kenny, 2000). Indvidu yang menginginkan hubungan romantis akan melakukan kontak secara rutin, melakukan aktifitas bersama, dan sedikit atau tidak membicarakan hubungan romantis lainnya dibandingkan dengan individu yang ingin hubungannya tetap platonik (Guerrero \& Chavez, 2005). Individu yang memiliki keinginan romantis melakukan kontak dan aktifitas bersama secara rutin sebagai cara untuk mendapatkan perilaku yang sama dari individu yang disukainya, dan sebagai cara untuk mengukur tingkat keinginan romantis individu yang disukainya.

Strategi lain yang dilakukan VN adalah tidak menanyakan hubungan romantis AL. Hal tersebut dapat dikategorikan sebagai topic avoidance atau menghindari topik pembicaraan tertentu. Beberapa penelitian mengungkapkan bahwa dalam mempertahankan hubungan persahabatan lawan jenis, individu yang terlibat menghindari konflik dengan tidak membicarakan topik yang tabu dengan sahabatnya (Lee, 2010). Beberapa topik tabu yang biasanya dihindari adalah pembicaraan mengenai status hubungan yang dijalani, hubungan romantis satu sama lain, dan ketertarikan terhadap sahabat. Tidak hanya VN yang menghindari membicarakan hal tersebut, AL juga mengatakan bahwa dirinya tidak ingin membahas hubungan mereka yang dulu karena baginya masih banyak topik lain yang dapat dibicarakan. Pembicaraan tabu apabila dilakukan memiliki resiko terjadinya konflik atau menimbulkan perasaan negatif, dalam hal ini perasaan negatif mengenai kegagalan hubungan romantis mereka. Individu menghindari beberapa topik pembicaraan karena akan menimbulkan ketidaknyamanan (Afifi \& Guerrero, dalam Monsour, 2002), namun 
untuk kalangan tertentu topik tersebut dapat dibicarakan bersama-sama seperti mengungkapkan perasaan terhadap satu sama lain (Monsour, 2002). Walaupun sudah membicarakan hubungan mereka yang telah lalu sebagai salah satu cara untuk mengembalikkan hubungan seperti semula, VN tidak mengungkapkan perasaan sukanya kepada AL setelah hubungan mereka berakhir. VN merasa takut menerima kenyataan jika AL tidak merasakan perasaan yang sama dengannya. Individu yang berada pada kondisi menginginkan hubungan romantis (desires romance) menghindari membicarakan perasaannya terhadap sahabat lawan jenisnya karena adanya perasaan takut akan penolakan (Guerrero \& Chavez, 2005).

AL adalah pihak yang menolak hubungan romantis (rejects romance), meskipun ia mengetahui bahwa VN masih ingin melanjutkan hubungan tersebut. Setelah menjalin kembali hubungannya dengan $\mathrm{VN}, \mathrm{AL}$ menjaga jarak terhadap VN agar VN tidak salah menilai AL. AL tidak menginginkan kedekatannya kepada VN mengarah kembali pada hubungan romantis. Individu yang menolak hubungan romantis akan berhati-hati agar tidak mengembangkan potensi hubungan romantis dalam pertemanannya (Guerrero \& Chavez, 2005). AL dalam wawancaranya mengatakan bahwa dirinya berperan sebagai pengatur jarak dalam hubungannya dengan VN. AL mengatur jarak diantara dirinya dan $\mathrm{VN}$ agar VN tidak mengira bahwa dirinya menginginkan hubungan romantis.

\section{Kesimpulan}

Pertemanan lawan jenis pada dewasa muda menghadapi tantangan yang dapat berbeda dengan pasangan lainnya. Tantangan yang ditemukan dalam penelitian ini adalah tantangan menghadapi situasi romantis dan tantangan pihak eskternal pada pertemanan platonik. Tantangan situasi romantis merupakan tantangan yang muncul ketika individu yang berlawanan jenis mengalami situasi yang seharusnya dirasakan oleh pasangan romantis. Tantangan ikatan emosional ditemukan pada pasangan yang sempat menjadi pasangan romantis atau mutual romance. Tantangan baru self-image ditemukan pada individu yang memiliki kepedulian yang tinggi atas penilaian orang lain terhadap dirinya. Penelitian ini juga menunjukkan bahwa hubungan persahabatan dapat terjalin kembali setelah individu mengalami kegagalan dalam hubungan romantis yang dijalani sebelumnya. Strategi mempertahankan hubungan dalam pertemanan lawan jenis dipengaruhi oleh pandangan individu terhadap hubungan yang dijalaninya. Pasangan yang melihat hubungannya sebagai pertemanan platonic membicarakan hubungan romantis kepada sahabatnya, tidak memikirkan pandangan pihak eksternal mengenai pertemanannya, dan mengalihkan pembicaraan jika menghadapi situasi romantis. Pasangan pertemanan romantis ketika hubungan romantis berakhir, individu yang masih menginginkan hubungan romantis akan menghindari membicarakan perasaan romantisnya kepada sahabatnya dan individu yang menolak menjalin hubungan romantis akan menjaga jarak dan batasan antara ia dan sahabatnya agar sahabatnya tidak salah mengartikan perilakunya. Secara umum, terdapat strategi mempertahankan hubungan yang ditemukan pada kedua pasangan, seperti menjaga komunikasi tetap berlangsung, melibatkan satu sama lain dalam kehidupan masing-masing dan menghabiskan waktu bersama. 


\section{Saran}

Pihak yang menjalani hubungan ini akan terbantu untuk mempertahankan hubungan jika hubungan yang dijalani memiliki kejelasan tujuan. Tujuan yang dicapai sebaiknya dimiliki kedua individu, karena tujuan yang berbeda akan menyebabkan hubungan sulit untuk dipertahankan dan beresiko mengalami kegagalan. Untuk peneliti yang tertarik melakukan penelitian dengan tema ini sebaiknya berfokus pada faktor-faktor yang memengaruhi pertemanan lawan jenis seperti faktor budaya, lingkungan sosial, dan etnis. Hal ini dapat membantu memahami lebih dalam mengenai dinamika pertemanan lawan jenis di Indonesia.

\section{Kepustakaan}

Afifi, W. A., \& Faulkner, S. L. (2000). On being 'just friends': The frequency and impact of sexual activity in cross-sex friendships. Journal of Social and Personal Relationships, 17(2), 205222. doi: $10.1177 / 0265407500172003$

Baron, R. A., \& Branscombe, N. R. (2012). Social psychology. USA: Pearson.

Baumgarte, R. (2002). Cross-gender friendship: The troublesome relationship. In R. Goodwin, \& D. Cramer, Inappropriate relationship. New Jersey: Lawrence Erlbaum Associates.

Canary, D. J., \& Stafford, L. (1992). Relational maintenance strategies and equity in marriage. Communication Monographs, 59(3), 243-267. doi: 10.1080/ 036377592 09376268

DeVito, J. (1995). The interpersonal communication book. New York: Harper Collins College Publishers.

Feist, J., \& Fiest, G. J. (2009). Theory of Personality (7th ed.). McGraw-Hill.
Guerrero, L. K., \& Chavez, A. M. (2005).

Relational maintenance in cross-sex friendship characterized by different types of romantic intent: An exploratory study. Western Journal of Communication, 69(4), 339-358, doi: 10.1080/10570310500305471

Helgeson, V. S. (2012). Psychology of gender. USA: Pearson.

Kaplan, D. L. (1999). Developing classifications of cross-sex friendships between heterosexual young adults. Illinois: UMI.

Lee, P. (2010). Friendships after break-ups: Relational maintenance strategies in cross-gender post-dating relationships in Taiwan. Intercultural Communication Studies, 19, 38-53.

Michener, H. A., \& John D, D. (1999). Social psychology. Orlando: Earl McPeek.

Miller, R. S. (2015). Intimate relationship (Vol. VII). New York: McGraw-Hill.

Monsour, M. (2002). Women and men as friends : Relationships across the life Span in the 21st century. USA: Lawrence Erlbaum Associates.

O'Meara, J. D. (1989). Cross-sex friendship: Four basic challenges of an ignored relationship. Sex Roles, 21(7-8), 525544.

Rawlins, W. K. (1982). Cross-sex friends and the communicative management of sex-role expectations. Communication Quarterly, 30, 343-352. doi: 10.1080/01463378209369470

Robinson, K. (2016). Young identities and social transformations in modern Indonesia. Leiden: Kitlv.

Santrock, J. W. (2011). Life span development. New York: McGraw-Hill.

Schneider, C. S., \& Kenny, D. A. (2000). Cross sex friends who were once romantic partners: Are they platonic friends now? Journal Social and Personal Relationship, 17(3), 453-469. 
Schoonover, K., \& McEwan, B. (2014). Are you really just friends? Predicting The Audience Challenge in CrossSex Friendships. Personal Relationships, 21, 387-403, doi: 10.1111/pere. 12040
Sprecher, S., \& Regan, P. C. (2002). Liking some things (in some people) more than others : Partner preferences in romantic relationships and friendships. Journal Sosial and Personal Relationship, 19(4), 463-481, Sage Publications. 